\title{
Affordable Housing Programme in Kenya: Policy Guidelines and Milestones
}

\author{
Job Omagwa, $\mathrm{PhD}$ \\ School of Business, Kenyatta University, Kenya, B.O Box 43844- 00100 Nairobi, Kenya
}

\begin{abstract}
The paper presents an overview of policy interventions and milestones by the Government of Kenya with regards to the Affordable Housing programme targeting civil servants, members of the Kenya Police Service and Kenyan Citizens. The programme was initiated by the Government to supply 500,000 homes over a period of 5 years in line with the Government's Big Four Agenda, Kenya Vision 2030 and Kenya Constitution 2010. The paper presents a Financing Framework through which Citizens could eventually buy or rent a home cheaply. A highlight of the housing gap in Kenya is presented as well as the residential housing affordability challenges faced by most Kenyan Citizens. The paper highlights the eligibility criteria for affordable housing (through the Bomayang $u$ online platform), the financing framework (for raising capital to buy a home) as well as partnerships between the Government of Kenya and other external stakeholders such as governments and private companies. Through the State Department of Housing and Urban Development, the Kenya Government has initiated several affordable housing projects in Nairobi and Kisumu Cities as well as Embu and Machakos Towns. In addition, slum upgrading programmes are on course in Kibera slums, Nairobi as well as other parts of Kenya. Lastly, the paper highlights the contribution to various stakeholders as well as housing finance theory where limited literature exists on such government initiated programmes.
\end{abstract}

Keywords: Affordable Housing, Civil Servants, Civil Servants Housing Scheme, Housing Fund, Government Housing, Big Four Agenda and Kenya Vision 2030.

DOI: $10.7176 / \mathrm{PPAR} / 11-2-01$

Publication date:March $31^{\text {st }} 2021$

\section{Introduction}

Affordable housing programme comprises of the supply side, demand side and enablers (land, infrastructure, tax incentives, tax breaks etc.); the programme targets low income persons, middle and high income segments with particular emphasis to closing the low-income housing gap by $60 \%$, create 350,000 jobs in the construction sector and increase contribution to GDP (Affordable Housing Delivery Framework, 2018). Kenya's revised National Housing Policy, Sessional Paper No.3 of 2004 sought to address the deteriorating housing conditions countrywide and to bridge the shortfall in housing especially in urban Areas and addressing the issue of safer neighbourhoods (WorldBank, 2011; Nabutola, 2004). The Government of Kenya came up with Affordable Housing as one of the government's priority areas under the Big Four Agenda to ensure that the Citizens would have an opportunity to buy houses at affordable prices with better quality housing environment. Kosgei and Rono (2018) indicate that affordable housing is a key economic development pillar that the Kenya Government is pursuing to bolster economic growth and development.

Article 43 of Chapter 4 of Kenya Constitution 2010 indicates that every person has a right to accessible and adequate housing and to reasonable standards of sanitation. Hence, affordable housing (in the context of Big Four Agenda on Housing implies developing adequate, standardized housing as well as continuous supply of water and electricity (www.kippra.or.ke). This applies to government housing as well as commercial residential housing. The Kenyan government targets supply of 500,000 affordable housing units by year 2022 (bomayangu.go.ke; www.kippra.or.ke). Providing affordable housing in Kenya has become challenging especially due to the growth in Kenya's population. Developing good infrastructure equally means providing clean water, good transport network, sanitation and communication system (www.kippra.or.ke).

In Kenya, The State Department of Housing and Urban Development in the Ministry of Transport, Infrastructure, Housing and Urban Development is in charge of the Affordable Housing Programme. The department seeks to supply 500,000 new affordable housing units over a five year period through lowering the cost of construction, improving accessibility to mortgage financing and upgrading slums. About 300,000 Kenyan citizens have since registered to buy the houses (www.housingandurban.go.ke). Through a five year project pipeline, the government plans to develop affordable housing units in 5 lots with lot number one targeting 35,940 units in: Ngara, Parkroad, Makongeni, Shauri Moyo A, B, C and D, Starehe A \& B, Mavoko. The slum upgrading and social housing programme is equally part of the affordable housing programme by the government of Kenya (Affordable Housing Delivery Framework, 2018)

Eligibility criteria and financing have been clearly spelt out by the State Department of Housing and Development. To be eligible one has to register online via bomayangu online site created by the Ministry. Eligibility entails one being a Kenyan citizen with a valid Identification Card and should be 18 years and above. 
Such applicants should specify the type of house they prefer and could contribute singly (voluntary contribution) or joint contribution with a spouse or some other family member. If one does not get allocated a house, they can access their contributions on the sooner of 15 years after the first contribution or upon attaining retirement age whichever comes first (bomayangu.go.ke). In view of Affordable Housing Delivery Framework (2018), financing framework, the Housing Fund will be the main purchaser of housing units from developers and similarly the long term financier offering home owners affordable and accessible funding to purchase homes through the National Tenant Purchase Scheme. The Housing Fund will mobilize capital from Government via $3 \%$ contribution by employer/employee, development finance institutions, local banks and affordable housing home owners' savings plans.

The construction of housing projects in Embu, Machakos County and Kisumu County has been financed by the Civil Servants Housing Scheme Fund for civil servants. Interested civil servants are advised to apply for the houses in view of their grades as well as their capacity to repay (bomayangu.go.ke). National Police Service Officers are equally eligible to apply. An objective point-based criteria is set to be used in allocating the houses once they are advertised for sale. Such allocations will be limited to one house per civil servant and priority being given to first time beneficiaries under the scheme (www.housingandurban.go.ke). This is to ensure fairness in allocation of the houses since about 300,000 Kenyan citizens have applied for the same yet supply of affordable housing is low. The annual demand for housing has increased steadily especially in Nairobi. The annual need for housing in Kenya was estimated at 206,000 units in year 2014 with $40 \%$ of the needs being in urban centres yet supply was limited to a paltry 50,000 units (Omagwa, 2014). WorldBank (2011) found that ony $11 \%$ of the urban population in Kenya could afford mortgage financing. With these limitations, the affordable housing programme would create an environment for more Kenyans to buy houses.

Arvanitis (2013) indicates that in year 2004, the Government of Kenya initiated the Civil Servants Housing Scheme Fund meant to provide loan facilities to civil servants for purposes of purchasing or constructing residential homes and developing housing units for sale and rental by civil servant. Affordable housing programme was equally rolled out to cater for housing needs for civil servants, members of the national police service and the general public. Mburu and Kakumu (2013) document a low level of home ownership despite growth in mortgage portfolio. According to Section 5 of the Social Pillar of Kenya Vision 2030 on Housing and Urbanization, the Kenyan Government seeks to address the problem of affordable housing, social equity and a secure living environment. These are key tenets of government housing for rental and home ownership.

Muthoka (2011) acknowledges that most real property investors in Kenya have some information gap and may still not consider the services of brokers who are in most cases better informed. However, the brokers' vested interests and costs associated with providing information to the buyers complicate the buyers' real property investment decisions. Kyambo (2011) contends that most real property buyers in Kenya make mistakes by trying to carry out the investment process on their own without soliciting for professional help. Hence, in view of affordable housing, the State Department of Housing and Urban Development has been key in providing citizens with relevant information about the affordable housing programme through bomayangu.go.ke cite as well and the website for the Ministry that is www.housingandurban.go.ke. Affordable housing is key since it is a basic need and most Kenyans in urban centres spend much of their income on rent; the cheapest home formally constructed would cost about $\$ 15,000$ which still ends up being quite expensive for most Kenyans (Affordable Housing Delivery Framework, 2018).

Kenya has a population of 47,564,296 persons (23.548 million male, 24.014 million females and 1,524 being intersex) constituting 12,143,193 households; the country's household size is 3.9 persons which is fairly high. Nairobi County has the highest populations of 4,337,080 with a household size of 2.9 persons and a total of 1,506,888 households. The country's population has been rising steadily: with the population being 28.7 million in year 1999 then rising to 37.7 million in year 2009, the numbers rose to 47.564 million in year 2019 with the population density being 82 per square kilometer (KNBA:2019 Kenya Population and Housing Census, Volume I, 2019). This is a clear indication of need for increasing supply in residential housing: the Kenyan government has since responded with the affordable housing programme to address the country's increasing need for housing.

\section{Affordable Housing Data and Financing Framework}

High housing congestion rates have been recorded in Nairobi unlike other towns and cities in Kenya: Beguy et al. (2010) and Rockefeller Foundation (2005) indicate that more than $25 \%$ of Kenya's population is housed in Nairobi; However, Nairobi occupies about $8 \%$ of Kenya's total land surface (Nabutola, 2004). Omagwa (2014) indicates that Nairobi accounts for about $25 \%$ of Kenya's urban population. Owning a home is quite expensive in Kenya especially in urban settings. WorldBank (2011) placed Kenya's annual housing need at 205,823 units with $40 \%$ of this needs being in urban centres; the urban population who can afford mortgage loans were placed at a paltry $11 \%$. Hence, the Kenya government sought to address this problem by initiating affordable housing programme under the Big Four Agenda.

Financing arrangements (for interested buyers under affordable housing programme) are spelt out in the 
regulations governing the operation of the scheme vide Legal Notice No. 98 of $15^{\text {th }}$ September, 2004; other financing arrangements are captured in Amendment Regulation of 2015 on the Civil Servants Housing Scheme Fund. Those interested in affordable housing are expected to save towards the same (via bomayangu platform), borrow from financiers such as commercial banks, apply for mortgage financing (for civil servants) form Civil Servants Housing Fund, pool financial resources with other family members such as spouses among other sources (bomayangu.go.ke). In view of Finance Act 2019, Kenya Government provides VAT exemptions for all inputs in affordable housing development schemes as well as tax incentives and tax breaks (zero rating of stamp duty for first time home owners) to make affordable housing programme attractive and less costly (Affordable Housing Delivery Framework, 2018). The Kenyan government has equally waived National Environmental Management and National Construction Authority fees on construction of affordable housing units.

Kosgei and Tenai (2018) cite CAHF (2016) which indicates that Kenya Vision 2030 targets a supply of about 200,000 housing units annually though only 35,000 are produced. Citing Kenya Vision (2030), Omagwa and Aduda (2015) indicate that the Kenyan Government has adopted measures to lower the cost of mortgage financing for home buyers and construction housing. Despite these efforts, home ownership by government employees is quite low in Kenya. Mundra and Oyelere (2013) contend that securing a mortgage depends on the borrower's demographics such as wealth and their networks.

In Kenya, demand for housing is far too higher than supply. Despite the demand for urban housing in Kenya being about 300,000 units, only 15,000 units were developed in year 2013; low mortgage uptake has been recorded in the country with mortgages being estimated at 25,000 as of year 2018; demand for housing is constrained by lack of adequate funding, limited financial capacity to quality for mortgage and expensive mortgages (Affordable Housing Delivery Framework, 2018). The Kenyan Presidency seeks to develop about 100,000 affordable housing units via Memorandum of Understanding between the Government of Kenya and United Nations Office for Project Service (UNOPS); a further 200,000 affordable housing units will be developed between the Government of Kenya and other strategic partners (www.president.go.ke).

Arvanitis (2013) cites low mortgage penetration rates in Kenya that is $2.5 \%$ of outstanding mortgages to GDP. Home ownership rates are quite low especially in urban settings like Nairobi where houses are quite expensive: Citing Hass Consult (2015), Kosgei and Rono (2018) indicate that the estimated price for apartments in Nairobi is about 11.58 million Kenya shillings. Though government houses may trade at much subsidized prices, their prices are fairly high for low and middle income citizens. Phipps (1988) contends that households are faced with a budget constraint which affects their housing decisions. Through affordable housing, the Kenyan government expects the contribution of real estate and construction to GDP to rise from the current $7 \%$ to $14 \%$ by year 2022 besides contributing towards job creation (Affordable Housing Delivery Framework, 2018).

There are several affordable housing projects currently undertaken while some are to be rolled out in due course (bomayangu.go.ke). These include: 1,2 and 3 Bedroom 1,370 Apartment Houses at Ngara, Parkroad (228 units for Phase I, 260 units in Phase II then the rest in Phase III); 220 units Civil Servant Houses in Embu Town (2 and 3 Bedroom); 200 units in Machakos (2 and 3 Bedroom) houses set for completion in mid-year 2020; 463 units (2-3 Bedroom Flats and Bungalows in Mavoko Sustainable Housing Programme; 4,400 units in Kibera Soweto East Zone B (1,2 and 3 rooms in highrise blocks of 12 floors; NHC Stoni Athi view (Economy Block for Rental) i.e. 20 bedsitters, 17 units for 1 bedroom and 7 units for 2 bedroom houses; NHC Stoni Athi view (all 4 bedroom houses Type A, B and C to cost sh. 8 million to sh. 9.75 million; 3,000 units Starehe Affordable Housing Project (1,2 and 3 bedroom houses) with mixed-use development with social, common and housing amenities and Mariguini Informal Settlement (a redevelopment of 2,600 residential units of 1,2 and 3 highrise blocks of 10 floors (bomayangu.go.ke). In view of slum upgrading programme, a total of 822 housing units have been completed in Kibera Soweto A; 1, 2 and 3 room houses were sold as rent-to-own with a 25 year tenure for monthly rent of sh. 2,500, sh. 4,500 and sh. 6,500 respectively; Kibera B-D are the next projects; 498 slums have been mapped country wide for purposes of improving housing conditions (Affordable Housing Delivery Framework, 2018).

\section{Affordable Housing Programme Updates and Milestones}

The Kenya Government has made significant strides in affordable housing programme since it was initiated. On $6^{\text {th }}$ December 2019, President Uhuru Kenyatta launched the Habitat Heights (8,888 units) at Machakos County, Kenya as part of the affordable housing programme projects undertaken by United Nations Office for Project Services (UNOPS). This would not only provide affordable housing to Kenyans but also create jobs and business opportunities to the locals. In addition, developing decent housing for Kenyans would also promote the Manufacturing pillar of the Big Four Agenda. The affordable housing inputs are to be sourced locally more so from Micro, Small and Medium Sized Enterprises; tax incentives would be extended to lower the construction cost. The Eastlands Urban Renewal Master plan is expected to supply an additional 168,000 units. The resettlement of Kibera Zone B residents will give decent homes to about 4,400 households (www.president.go.ke). 
The Ministry of Transport, Infrastructure, Housing, Urban Development and Public works (through the Office of Principal Secretary) announced the sale of constructed houses in Ngara, Parkroad Nairobi, Embu, Machakos, Kiambu and Kisumu. In Ngara, Parkroad, the provisional selling price for one-bedroom apartment is 1,500,000 Kenya shillings; two-bedrooms apartments would cost sh. 2,000,000 and sh. 2,500,000 for the two different sizes; three-bedrooms apartment would cost sh. 3,550,000 and sh. 4,000,000 for the two different sizes. A parking lot (in the parking silo) would be purchased separately for sh. 390,000 (Ministry of Transport, Infrastructure, Housing, Urban Development and Public Works, 2019).

The development of 1,370 affordable housing units along Ngara, Parkroad is soon being completed with first priority being given to Civil Servants particularly those who vacated the old Parkroad Estate to pave way for redevelopment of the affordable housing units. This was communicated by the Principal Secretary for State Department of Housing and Urban Development. The next project will be a Shauri Moyo and Starehe in Nairobi (www.president.go.ke). About 300,000 Kenyan citizens have since expressed interest in buying the houses along Ngara, Parkroad via the government's bomayangu.go.ke portal. The prospective buyers are required to be paying a monthly minimum deposit of sh. 200. Buyers who may not settle the full purchase consideration are expected to pay $10 \%$ deposit and settle the balance over the next 25 years under a rent-to-own arrangement (bomayangu.go.ke)

Prospective buyers are expected to have saved $12.5 \%$ of the selling price before getting a mortgage to enable them clear the outstanding balance at $9 \%$ interest for up to 25 years. Investors have since committed over sh. 1 trillion towards the affordable housing programme in partnership with the Government of Kenya. For instance, United Nations Office for Project Services (UNOPS) has since committed sh. 500 billion to develop 100,000 affordable housing units in Athi river, Kenya (www.dailynation.org). The first batch of 228 units were completed and handed over to the government in January 2020.

\section{Value of the Review}

This paper is of value in different ways. It seeks to sensitive Kenyans on the available opportunities (thro Government of Kenya) on owning a home through cheaper financing arrangements; the paper makes a contribution to the existing body of knowledge on affordable housing programmes especially in developing economies (such as Kenya) where the demand for cheaper housing far outweighs the supply of housing; the paper enumerates the successes that the Kenya government has made in terms of realizing its objective of supplying 500,000 homes in a period of 5 years; it also documents the programmes that the government has rolled out in terms of upgrading housing environment through improving infrastructure and neighbourhood conditions for residential housing. In addition, the paper highlights the financing framework that the government has put in place for raising capital besides the partnerships between the government and other foreign private partners; the paper further seeks to market the affordable housing projects that the government has completed as well as those which are on course for Kenyans to plan on how to buy a home; lastly, the paper highlights how household demographic characteristics affect affordability of housing especially among the middle and low income earners in Kenya.

\section{Summary}

The paper presents an overview of the Government of Kenya framework for providing affordable housing (for purchase and rental) to civil servants, members of the police service and the general public. A highlight of the housing gap in Kenya is provided as well as Government's efforts to enhance supply of affordable housing via partnerships with private firms and other international bodies: this is in line with the Country's Big Four Agenda and Kenya Vision 2030. Through the Bomayangu.go.ke platform, the government has documented information about the Citizen's eligibility for affordable housing, application criteria for purchasing a unit and relevant information about on-going projects through the State Department of Housing and Urban Development. The paper presents a financing framework (mainly via Civil Servants Housing Scheme Fund) through which citizens can purchase affordable housing units. A brief highlight of slum upgrading initiatives is equally documented. A highlight of complete and on-going developments is captured with respect to Nairobi, Machakos, Embu and Kisumu County governments.

\section{References}

Arvanitis, Y. (2013). African Housing Dynamics: Lessons from the Kenyan Market. Africa Economic Brief, 4 (3).

Beguy, D., Bocquier, P. \& Zulu, E. M. (2010). Circular Migration Patterns and Determinants in Nairobi Slum Settlements. Demographic Research, 23 (20), 549-586.

Case K. and Shiller R. (1989). "The Efficiency of the Market for Single-Family Homes", The American Economic Review. 79 (1), 125-137.

Clauretie T. and Sirmans G. (2006). Real Estate Finance. Theory and Practice. Australia: Thomson South 
Western.

Clayton J. (1998). Further Evidence on Real Estate Market Efficiency, Journal of Real Estate Research, 4157.

Cronin F. (1982). "The Efficiency of Housing Search", Southern Economic Journal.48, 1016-1030.

Doling. J. (2008). Housing and Demographic Change. OTB Research Institute for Housing, Planning and Mobility. Delf University of Technology Studies, Netherlands.

Dowd K. (2009). Moral Hazard and The Financial Crisis. Cato Journal, 29 (1).

Fu. Y. and Ng. L. (2001). Market Efficiency and Return Statistics: Evidence from Real Estate and Stock Markets Using a Present-Value Approach. Real Estate Economics 29, 227- 250.

Galvez M. and Kleit R. (2011). The Location Choices of Public Housing Residents Displaced by Redevelopment: Market Constraints, Personal Preference or Social Information? Journal of Urban Affairs. 33, (4).

Gichuki, G. (2011), "Why there is a Property Boom in Kenya", Biashara Leo. June/July 2011.

Heath. A. (1976). Rational Choice and Social Exchange. Cambridge: Cambridge University Press.

Ito. T. and Hirono K. (1993). Efficiency of the Tokyo Housing Market, Working Paper Series, Working Paper No.4382, National Bureau of Economic Research.

Kairu G. (2005), "In the Interest of Safer Homes", Homes Kenya. February/March 2005.

Kapoor, J. Dlabay, L and Hughes, R. (2007) Personal Finance ( $8^{\text {th }}$ Rd.) Boston: Irwin.

Kau J., Keenan D., Lyubimov C., and Slawson V. (2010). Asymmetric Information in the Subprime Mortgage Market. US: University of Georgia, February 25, 2010.

Kyambo, K. (2010), "The Timeless Wisdom of Investment in Property.”, The Property Zone. May 2010.

Kyambo, K. (2011), "Major mistakes to avid in Real Estate Investment.", The Property Zone.May 2011.

Kosgei, M. (2018). Determinants of Residential Housing Prices in Nairobi County, Kenya. Moi University, Kenya. Unpublished PhD Thesis

Kosgei, M \& Rono, L. (2018). Effect of GDP, Population and Interest Rate on Residential House Prices in Nairobi County, Kenya. European Journal of Business and Management, 10 (24).

Kosgei M. \& Tenai, J. (2018) Effect of selected demographic and macro-economic variables on house prices in nairobi county, Kenya. International Journal of Economics, Commerce and Management, 6 (8).

Lambson V., McQueen G. and Slade B. (2007) Do Out-of-State Buyers Pay More for Real Estate? An Examination of Anchoring-Induced Bias and Search Costs. Real Estate Economics. 1, 85-125.

Littlewood A. and Munro M. (1997). Moving and Improving: Strategies for Attaining Housing Equilibrium. Urban Studies 34 (11). 1771-1787.

Lofgren K., Persson T. and Weibull J. (2002). "Markets with Asymmetric Information: The Contributions of George Akerlof, Michael Spence and Joseph Stiglitz. The Scandinavian Journal of Economics. 104 (2), 195-211.

Maier G. and Herath S. (2009). Real Estate Market Efficiency: A Survey of Literature. Research Institute for Spatial and Real Estate Economics.

Mburathi K. (2010)" Criteria for Purchasing Commercial Space", The Property Zone. November, 14-15.

Mburathi K. (2011)” Why use an architect?", The Property Zone”, February, 2011,32-33.

Muthoka, T. (2011). "Investment A B C...the Beginner's Class”, The Property Zone. May 2011 edition.

Mundra, K., \& Oyelere U. (2013). Determinants of Immigrant Home Ownership: Examining their Changing Role During Great Recession and Beyond. IZA Discussion Paper 7468.

Mburu, L \& Kakumu, O. (2013). Determinants of Mortgage Uptake in Kenya using the Capital Market Approach, SHRD Annual Research Conference, JKUAT, 12-13.

Mwangi W. (2009). Institutional Reforms the Panacea to Land Reforms. The Land and Property Digest, 8 (2009), 11-13.

Northcraft G. \& Neale M. (1987). Expert, Amateurs, and Real Estate: An Anchoring- and-Adjustment Perspective on Property Pricing Decisions. Organizational Behaviour and Human Decision Process 39: 8497.

Ojijo D. (2005) "Buying a home”, Homes Kenya Magazine. February/March 2005 edition.

Okoth, J (2010)." Government Paper Puts Pressure on Mortgage Rates”, The Standard Financial Journal. P.7. Nairobi, Kenya.

Omagwa, J. (2014). Demographics, Housing Search, Asymmetric Information and Housing Decisions Among Apartment Households in Nairobi City County, Kenya. Unpublished PhD Thesis. University of Nairobi, Kenya.

Omagwa J. \& Aduda J. (2015). The Mediating Effect of Housing Search on the relationship between Demographics and Residential Housing Decisions Amongst Apartment in Nairobi County, Kenya. Journal of Advances in Management \& Applied Economics, 5 (4).

Omagwa, J. \& Aduda, J. (2015). The Influence of Demographics on Owner-Occupied Housing Decisions: A Case of Apartment Households in Nairobi County, Kenya. Business \& Entrepreneurship Journal, ISSN: 
2241-3022.

Omagwa, J. \& Wamugo, L. (2016). A Profile of Urban Owner-Occupied Residential Households' Characteristics in Nairobi City County, Kenya. Developing Country Studies, 6 (7), 2016128.

Oundo Wilberforce O (2011). Unpublished PhD Thesis in Land Economics. Department of Real Estate and Construction Management. School of Built Environment, University of Nairobi.

Owaga W. (2010). "Investing in Commercial Real Estate", The Property Zone. November, 2010, 10-11.

Nabutola, W. (2004). Affordable Housing in Kenya: A Case Study of Policy on Informal Settlements. TSC-Land Administration and Housing Issues in Informal Settlements. $3^{\text {rd }}$ FIG Regional Conference, Jakata, Indonesia.

Phipps A. (1988). Rational versus Heuristic Decision Making during Residential Search. Geographical Analysis. 20 (3).

Quigley T. and Weinberg D. (1977). Intra-Urban Residential Mobility: A Review and Synthesis. International Regional Science Review, 2, 41-66.

Rockefeller Foundation (2005). Setting the Context: Kenya. More Than Shelter: Housing As An Instrument of Economic and Social Development. A Joint Centre for Housing Studies International Housing Conference.

Rossi P. (1955). "Why Families Move". Glencoe, Illinois: The Free Press.

Scott J. (2008). "Rational Choice Theory". Retrieved 2008-07-30.

Sharpe W., Alexander G. and Bailey J. (2004). Investments (6 ${ }^{\text {th }}$ ed). NewDelhi: Prentice-Hall of India.

Smith T., Clark W., Huff J. and Shapiro P. (1979). A Decision-Making and Search Model for Intra Urban Migration. Geographical Analysis, 11 (1).

Tan, Tech Hong (2008). Determinants of Home Ownership in Malaysia. Habitat International, 3 (3), 318-335.

Turnbull G. and Sirmans C. (1993). Information, Search, and Housing Prices. Regional Science and Urban Economics 23(4): 545-557.

Wambugu, J. (2011), "Why there is a Property Boom in Kenya", Biashara Leo. June/July 2011.

Wang. Z. (2004). Dynamics of Urban Residential Property Prices- A Case of the Manhattan Market. Journal of Real Estate Finance and Economics 29 (1): 99-118.

Wanja (2010), "Real Estate Professionals", Real Estate Monthly, May 2010.

Watkins. G. (1998). Are New Entrants to the Residential Property Market Informationally Disadvantaged? Journal of Property Research, 15, 57-70.

Wheaton W. (1990). "Vacancy, Search and Prices in a Housing Market Matching Model", Journal of Political Economy. 98.

World Bank, 2011. Developing Kenya’s Mortgage Market. World Bank Report No. 63391-KE. International Bank for Reconstruction and Development.

Biashara Leo Magazine (2011). The Property Boom. Is it Sustainable? June/July 2011.

Focus on Property, Kenya's Complete Property Guide. June 2013 edition. Vol. 14/ Issue 9.

Housing Finance- Mortgage Lending Requirements (2012).

Homes Kenya Magazine, Issue 44. Vol. VII. April- May 2013.

Affordable Housing Delivery Framework (2018)

The Constitution of Kenya (2010), Kenya Gazette Supplement No. 55. Nairobi: The Government Printer.

The Kenya Vision 2030, (2007). Government of the Republic of Kenya, Ministry of Planning and National Development and the National Economic and Social Council (NESC), Office of the President.

Nairobi: Government of Kenya.

www.housingandurban.go.ke

www.president.go.ke

www.ministryoflocalgovernment.go.ke

www.housing.go.ke

www.kippra.or.ke

bomayangu.go.ke 